\title{
Corrigendum: Sexual dimorphism in the effects of exercise on metabolism of lipids to support resting metabolism
}

\section{Gregory C. Henderson*}

Newomics Inc., Emeryville, CA, USA

${ }^{*}$ Correspondence: ghender21@hotmail.com

Edited and reviewed by:

Frontiers in Endocrinology Editorial Office, Frontiers, Switzerland

Keywords: gender, fat metabolism, Lipids, physical activity, metabolic rate

\section{A corrigendum on}

Sexual dimorphism in the effects of exercise on metabolism of lipids to support resting metabolism

by Henderson GC. Front Endocrinol (2014) 5:162. doi:10.3389/fendo.2014.00162

\section{Amendment}

Current address of the author is Newomics Inc., Emeryville, CA.
Conflict of Interest Statement: The author declares that the research was conducted in the absence of any commercial or financial relationships that could be construed as a potential conflict of interest.

Received: 28 October 2014; accepted: 12 November 2014; published online: 27 November 2014.

Citation: Henderson GC (2014) Corrigendum: Sexual dimorphism in the effects of exercise on metabolism of lipids to support resting metabolism. Front. Endocrinol. 5:200. doi: 10.3389/fendo.2014.00200

This article was submitted to Diabetes, a section of the journal Frontiers in Endocrinology.
Copyright (c) 2014 Henderson. This is an open-access article distributed under the terms of the Creative Commons Attribution License (CC BY). The use, distribution or reproduction in other forums is permitted, provided the original author(s) or licensor are credited and that the original publication in this journal is cited, in accordance with accepted academic practice. No use, distribution or reproduction is permitted which does not comply with these terms. 